\title{
Хронотоп повести А. Чехова "Скучная история"
}

\author{
Елена Василевич ${ }^{1}$
}

\begin{abstract}
:
The purpose of this article is to analyze Tchekhov's novel "Skutchnaia Istoriia". The theoretical approach is the concept of cronotopos developed by Mikhail Bakhtin.
\end{abstract}

Keywords: Anton Tchekhov; Mikhail Bakhtin; Russian Literature

...Будучи пространственно

ограниченным, произведение искусства представляет

собой модель безграничного мира.

Ю.Лотман

К концу 80-ых годов на смену известному молодому автору юмористических рассказов Антоше Чехонте приходит Антон Чехов с уже сложившейся новой стилистикой, новым подходом к прозе и драматургии, которые не сразу были поняты и оценены современниками, и до сих пор являются предметом многочисленных исследований. Одна из основных трудностей в понимания Чехова состоит в его особом отношении к роли автора в произведении. Чехов не декларирует свои взгляды, не вкладывает свое отношение к жизни в уста своих героев. То, что говорят или думают чеховские персонажи принадлежит только им.

Повесть "Скучная история", относится к тому типу чеховских произведений, где уловить позицию автора еще сложнее, чем в драматургии, произведений, написанных от лица персонажа, поскольку в них отсутствуют даже авторские ремарки. Тем важнее и интереснее представляется проанализировать, как "подтекст" раскрывает глубину содержания, какую роль играют "случайные" детали, композиция, воспоминания, лексика, стилистика, пространство и время в повести и, проанализировав это, проследить, как все эти средства, складываясь в единую художественную систему, ведут к разгадке чеховского подтекста.

"Скучная история " написана от лица героя. Николай Степанович - знаменитый ученый, врач, знает, что смертельно болен и пишет отрывистые "записки", цель которых - то ли разобраться в новых тревожных мыслях, то ли отвлечься от них , содержание их размышления о собственной жизни, о своих близких и знакомых, о науке, об искусстве, описание событий , воспоминания и т.д. Некоторые темы в "записках" развиваются, выводы в них либо остаются неизменными, либо меняются на противоположные, некоторые темы появляются эпизодически, "случайно", некоторые затронуты под влиянием болезни или настроения.

Все происходит "как бы" без участия автора, что позволяет читателю сложить собственное мнение о личности и трагедии Николая Степановича и почувствовать чеховское отношение не только к герою, его размышлениям, настроениям, страху, но и понять философское содержание самой повести.

Частично проделанная нами работа уже позволила сформироваться отчетливому

\footnotetext{
${ }^{1}$ Doutoranda no Programa de Pós-graduação em Literatura e Cultura Russa, do Departamento de Letras Orientais FFLCH/USP
} 
ощущению, что именно хронотоп повести и является той основой, к которой тянутся все основные нити повествования, именно время и пространство являются главными героями чеховской повести.

Существенную взаимосвязь временных и пространственных отношений, художественно освоенных в литературе, мы будем называть хронотопом. ( М. Бахтин http://philologos.narod.ru/bakhtin/hronotop/hronmain.html)

Введенное М. Бахтиным понятие "хронотоп" в применении к литературным произведениям почти не рассматривалось в отношении чеховских произведений.

Анализируя материал по этому вопросу мы, прежде всего, будем отталкиваться от самого текста при рассмотрении лексики, композиции, стилистики, ритмики и т.д.

Как уже говорилось, и в драматургии, где есть авторские ремарки, и в прозаических произведениях, написанных, от лица автора, но, где происходящее дано глазами какого-либо героя (или героев) непросто понять идею самого автора, Тем более сложно сделать это в произведениях, написанных от первого лица, таких как "Рассказ неизвестного человека", "Моя жизнь" и исследуемая нами повесть "Скучная история", где прямого авторского текста нет, и основным ключом к разгадке "подтекста" становятся художественные средства, композиция, стиль, символы, метафоры, реминисценции и цитаты. Ключ к пониманию взаимосвязь всех этих компонентов и вплетение их в изображаемое художественное время и пространство.

Только обращаясь к этому ключу возможно уловить чеховский замысел, почти всегда отличающийся от взгляда его героя или героев, и увидеть совсем другую картину, словно проступающую сквозь видимую на первый взгляд, картину, гораздо более глубокую и обобщенную

Понять сложную "взаимосвязь временных и пространственных отношений" в произведении возможно только исследуя всю совокупность художественных авторских средств. С этой целью мы прежде всего обратимся к композиции повести.

1.

Общепринятое мнение критики состоит в том, что композицию"Скучной истории" составляет не традиционный сюжет, а поиск причины духовного неблагополучия жизни, выраженный в размышлениях, итогом которых является мысль об отсутствии "общей идеи".

Нам же представляется, что помимо этой, общепринятой, существует и вторая композиционная линия - линия жизни героя, которую при внимательном чтении можно воссоздать по разбросанным по тексту, иногда едва уловимым, иногда подробным, его воспоминаниям.Если проанализировать обе композиционные линии, соотнесенные в тексте с антитезой "прежде-теперь", можно заметить, как гармонично усложненная композиция вплетается в общий авторский замысел.

Если вычленить из текста и расположить хронологически (а намеки-зацепки для этого в тексте есть) каждый еле уловимый, например, воспоминание о купании детей или, наоборот, подробный ,эпизод, как, например, Катино увлечение театром, мы восстанавливаем не только картину жизни профессора (эпизоды касаются каждого десятилетия, и мы представляем его в 20, 30, 40, 50 лет, почти до нынешнего возраста, когда он пишет свои записки ), но и видим по небольшим намекам, как происходило изменение личности, что он потерял, и даже можем догадаться о причинах этого процесса. В эту композиционную линию включены его блестящая научная карьера, семейная жизнь, интерес к философии стоиков и история Катиной жизни. Все это Николай Степанович называет талантливо сделанной 


\section{композицией..}

Чем дальше вглубь уходят воспоминания, тем лиричнее становится стиль, нежнее лексика, шире, воздушнее пространство, бесконечнее время. В прошлом появляется живая музыка (в отличие от раздражающего ее восприятия в период написания записок), животные( в записках лишь метафорические упоминания животных), дети, вкусная еда ...

- Бывало, гуляю я по нашему семинарскому саду...-- рассказываю я.-- Донесет ветер из какого-нибудь далекого кабака пиликанье гармоники и песню, или промчится мимо семинарского забора тройка с колоколами, и этого уже совершенно достаточно, чтобы чувство счастья вдруг наполнило не только грудь, но даже живот, ноги, руки... Слушаешь гармонику или затихающие колокола, а сам воображаешь себя врачом и рисуешь картины -одна другой лучше. (А.Чехов, Москва, 1977, с.283)

Чем ближе воспоминание по времени к настоящему для героя периоду, тем текст ближе по стилистике к моменту теперь, становится суше, скучнее, равнодушнее, уже чувствуется безразличие к жизни близких, сохраняется только любовь к науке.

Последние по хронологии воспоминания относятся к возвращению Кати и фраза "Теперь Катя живет в полуверсте от меня"(А.ЧЕХОВ, Москва, 1977, с.273) словно соединяет прошлое и настоящее.

Переходя к рассмотрению размышлений героя, к тому, что традиционно и считается композицией, заметим плавный переход от линии прежде к теперь. По характеру, стилю письма, манере рассуждений мы видим того же Николая Степановича, что и по воспоминаниям, приближенным к этому периоду, с одной лишь, но очень существенной, разницей. Теперь он, знаменитый профессор медицины, знает, что смертельно болен, и ему начинает казаться, что его талантливо сделанная композиция … разлетелась в клочья.(А.Чехов, Москва, 1977, с.284, 307)

Мы попробуем проанализировать композицию, отталкиваясь не от размышлений героя, как это принято, а от самого текста, его стилистики, ритма, затрагивая некоторые лингвистические моменты, (соотносимые с антитезой прежде-теперь) в отношении категории хронотопа, то есть, от материала, который либо неисследован совсем, либо исследован очень мало.

Повесть написана в жанре записок и состоит из 6-ти глав.

Название, исходя из настроения и содержания "записок" принадлежит одновременно и Николаю Степановичу, именно он так определяет свою прожитую жизнь, и автору.

Первоначальное название повести "Мое имя и я" еще больше подчеркивало то, что название дано героем. Впоследствии, несмотря на уговоры Плещеева, которому окончательное название "Скучная история" не понравилось, Чехов наотрез отказывается его менять. Невозможно не заметить символический оттенок, появившийся в новом названии (понятие "скука" как символ бессмысленности и однообразия существования встречается во многих чеховских произведениях), символика его, несомненно, принадлежит уже автору, а не герою

Записки начинаются вполне традиционно - герой представляет самого себя и даже дает свой портрет. И заканчиваются тоже вполне традиционно - окончательное прощание героев. Все это традиционно с точки зрения "дочеховской" литературы, но не для самого писателя, для которого характерно повествование, как правило, начинающееся ниоткуда и открытый финал. Учитывая этот момент и, особенно то, загадочный предлог из в подзаголовке "Из 
записок старого человека" - единственный прямой авторский текст , можно уже говорить о том, что "записки" героя не совпадают полностью с художественным произведением повестью "Скучная история".

Начиная с первой же страницы наблюдается противопоставление :мое имя и я .Оно проходит через все записки до самого конца.

Есть в России заслуженный профессор Николай Степанович такой-то, тайный советник и кавалер; у него так много русских и иностранных орденов, что когда ему приходится надевать их, то студенты величают его иконостасом... Вообще на моем ученом имени нет ни одного пятна и пожаловаться ему не на что. Оно счастливо.

Носящий это имя, то есть я, изображаю из себя человека 62 лет, с лысой головой, с вставными зубами и с неизлечимым tiс'ом. Насколько блестяще и красиво мое имя, настолько тускл и безобразен я сам...(А.Чехов, Москва, 1977, с.251)

Важно заметить, что рассказ о себе герой начинает в 3-ем лице, подчеркивая разделение имени и самого себя. Имя, словно гоголевский "Нос" существует отдельно от человека. Это резкое разделение, помимо других аспектов, подчеркивает также различие временных и пространственных категорий между самим героем и его именем. Не случаен выбор героя, нехарактерного для Чехова - знаменитый на весь мир ученый. Умирающий человек живет в пределах ограниченного пространства и ограниченного времени, а имя его широко известно и надолго переживет его самого, психологическое пространство героя тесное, замкнутое и скучное, психологическое пространство имени - свободное и блестящее.

Прежде всего, следует начать с того, что почти вся повесть написана с употреблением глаголов настоящего времени, соответственно, несовершенного вида и не только в значении начавшегося раньше и продолжающегося к данному моменту действия, но и в значении ежедневно повторяющихся событий. Создается впечатление, что Николай Степанович заранее знает, что произойдет, и что ему скажут в каждый следующий момент.

Затем он бежит впереди меня и отворяет на моем пути все двери. В кабинете он бережно снимает с меня шубу и в это время успевает сообщить мне какую-нибудь университетскую новость. (А.Чехов, Москва, 1977, с.258)

Глагол сохраняет несовершенный вид даже в тех случаях, когда описываются единичные события:

Мое превосходительство ведут на улицу, сажают на извозчика и везут. Я еду и от нечего делать читаю вывески справа налево(А.Чехов, Москва, 1977, с.291)

С помощью стилистических средств с самого начала дается ощущение замкнутого круга те же события, разговоры, люди, ничего не меняется....Возникает трагическое противоречие жизнь топчется на месте, а время безвозвратно и бессмысленно уходит.

В 1-ой и 2-ой главе главах герой рассказывает о себе, словно пишет историю болезни сухим научным языком, описывает свой, день, утро, ночь, свою семью, коллег, лекции, пространно рассуждает о театре, женщинах. Лексика подчеркивает замедленность и незначительность событий, тоску, которая рождается в душе профессора:

неподвижно, машинально, томительное время, недоумение, я холоден, мысли жалят, ходить из угла в угол, мрачные, скучающие, ветхость, унылый вид, пессимизм.

Основным мучительным состоянием становится бессоница. День заполнен хотя и скучными, но событиями, ночью же именно во время бессоницы к нему и приходят "новые" 
мысли.

Бессоница - темнота и тишина, напоминающие о вечном покое, когда только звуки, движения, воспоминания, казалось бы, еще связывают его с жизнью, как переходное состояние между жизнью и смертью.

Что касается моего теперешнего образа жизни, то прежде всего я должен отметить бессонницу, которою страдаю в последнее время. Если бы меня спросили: что составляет теперь главную и основную черту твоего существования? Я ответил бы: бессонница...Не спать ночью -- значит, каждую минуту сознавать себя ненормальным, а потому я с нетерпением жду утра и дня, когда я имею право не спать. (А.Чехов, Москва, 1977, с.252)

По мере ухудшения здоровья, нагнетания страха и, очевидно, вследствие этого и замучавшей его бессоницы, раздражение у героя нарастает, его вызывает уже буквально все и люди, и литература, и театр, и университет, и научные статьи.

Когда человек не понимает, то чувствует в себе разлад; причин этого разлада он ищет не в себе самом, а вне себя, отсюда и война с тем, что он не понимает. ( А.Чехов http://ruslit.traumlibrary.net/book/chekhov-pss30-21/chekhov-pss30-21.html )

Говоря о себе, Николай Степанович останавливается на ослаблении профессиональных способностей, что для него намного болезненнее, чем изменения внешние.

Мы замечаем и то, что А.Степанов определил, как "стирание-старение знака". ( А.Степанов, http://my-chekhov.ru/kritika/problem/content.shtml

Знак нежности и любви, когда герой целует пальчики маленькой Лизе, любящей мороженое, приговаривая; "фисташковый, малиновый"...превращается в привычку, и, целуя пальцы взрослой Лизы, он чувствует фальшь и неловкость. То же самое можно сказать об обедах. Если раньше они были знаком единения счастливой семьи, то теперь превращаются в свою противоположность и лишь подчеркивают отчужденность людей. Таких примеров в повести много.

Первые три главы - описание одного дня. Спокойные рассуждения, которыми начинается каждая глава приводят в конце ее к эмоциональному взрыву, истерике и бегству ( в конце 2ой, 3-ей и 5-ой глав), герою необходимо вырваться из того пространства, в котором он на данный момент находится.

После взрыва - следующая глава. Переход - пауза, напоминающая паузы в его драматургических произведениях - и герою, и читателю дается возможность вздохнуть и осмыслить произошедшее.

Своих взрывов герой не понимает, всю жизнь он ориентировался только на мыслительный процесс, оставляя ощущения, эмоции и чувства в стороне. Источник их для него - болезнь, но, главное, эти сильнейшие эмоциональные ощущения совершенно новы для него, непонятны, иррациональны, не поддаются, а часто противоречат его разумному подходу к жизни, талантливо сделанной композиции. По привычке он пытается дать им объяснение, облечь их в слова, уложить в сознании по полочкам, но и это не удовлетворяет его. Они остаются за пределами его понимания.

Этот процесс мы наблюдаем в первых 4-ех главах, которые в книжном варианте (А.Чехов Полное собрание сочинений и писем в 30 томах, Москва, 1977-1978) составляют 49 страниц, последние две главы составляют всего 10 страниц.

5-ая глава - концентрирует это непонимание, в ней уже нет рассуждений, герой весь отдается во власть своих ощущений.С самого начала главы ясно, что описывается единичное событие, слово одна и глагол прошедшего времени подчеркивают это. 
Бывают страшные ночи с громом, молнией, дождем и ветром, которые в народе называются воробьиными. Одна точно такая же воробьиная ночь была и в моей личной жизни... (А.Чехов, Москва, 1977, с.300)

Описание воробьиной ночи, которую пережил сам Антон Чехов мы находим в воспоминаниях его брата Александра.

Воробьиной ночью в Малороссии называется такая страшная грозовая ночь, что даже воробьи от испуга вылетают из своих гнезд и мечутся как угорелые по воздуху. ( Ал. Чехов ..http://az.lib.ru/c/chehow_aleksandr_pawlowich/text_0070.shtml

В этой главе все построено на контрасте. Ночь, хоть и названа "воробьиной" вовсе не грозовая, наоборот, великолепная - тихая и лунная. Гроза же - в "личной жизни" героев. И этот контраст прекрасной, равнодушной, вечной природы и человеческих страданий, конечности человеческой жизни, прежде всего, подчеркивает ужас и смятение, внезапно и необъяснимо возникшие в душах героев.

Погода на дворе великолепная. Пахнет сеном и чем-то еще очень хорошим. Видны мне зубцы палисадника, сонные тощие деревца у окна, дорога, темная полоса леса, на небе спокойная, очень яркая луна и ни одного облака. Тишина, не шевельнется ни один лист. Мне кажется, что все смотрит на меня и прислушивается, как я буду умирать... (А.Чехов, Москва, 1977, c.300-301)

Непереносимый страх, который переживает Николай Степанович (и другие герои), настолько иррационален, необъясним, возникает ниоткуда, почему-то охватывает сразу всех, что читателю передается атмосфера почти мистическая. Описание Кати, освещенной светом луны, тоже напоминает о чем-то нереальном, мистическом и страшном, заставляя вспомнить страшные сны или кладбищенскую тему.

Я отворяю окно, и мне кажется, что я вижу сон: под окном, прижавшись к стене, стоит женщина в черном платье, ярко освещенная луной, и глядит на меня большими глазами. Лицо ее бледно, строго и фантастично от луны, как мраморное, подбородок дрожит.

-- Это я...-- говорит она.-- Я... Катя!

При лунном свете все женские глаза кажутся большими и черными, люди выше и бледнее, и потому, вероятно, я не узнал ее в первую минуту. (А.Чехов, Москва, 1977, с.303)

Лунная ночь - один из символов, проходящий через все творчество Чехова, луна изменяет реальный мир, добавляет в него потустороннее, вечное, с ней связаны силы, независимые от человека и не только стихия природы, но и стихия человеческой души и ее проявления любовь, ненависть, страх, тоска (скука), часто не имеющие причин, экзистенциальные. Луна отражает что-то кажущееся, обманчивое, связанное со смертью.

На первых порах Старцева поразило то, что он видел теперь первый раз в жизни и чего, вероятно, больше уже не случится видеть: мир, не похожий ни на что другое, — мир, где так хорош и мягок лунный свет, точно здесь его колыбель, где нет жизни, нет и нет, но в каждом темном тополе, в каждой могиле чувствуется присутствие тайны, обещающей жизнь тихую, прекрасную, вечную. (А.Чехов, Москва, 1977, с.31) 
Поднимается занавес; открывается вид на озеро; луна над горизонтом, отражение ее в воде; на большом камне сидит Нина Заречная, вся в белом.

...Уже тысячи веков, как земля не носит на себе ни одного живого существа, и эта бедная луна напрасно зажигает свой фонарь. (А.Чехов, Москва, 1978, с.13)

И, хотя, как и в предыдущих четырех главах почти все глаголы употребляются здесь в настоящем времени, они, также, как ритм и лексика, подчеркивают уже не повторяемость происходящего, а резкое замедление времени, словно фиксируется каждый миг. Время почти останавливается.

Тишина мертвая, такая тишина, что, как выразился какой-то писатель, даже в ушах звенит. Время идет медленно, полосы лунного света на подоконнике не меняют своего положения, точно застыли... Рассвет еще не скоро. (А.Чехов, Москва, 1977, с.303)

Тишина, покой, неподвижность природы и времени, напоминающие о "вечном покое" - и на контрасте с этим появляются слова "быстро", "вдруг", "спешу", "чаще и чаще", "прыгают", "гонится", "хочет схватить", "внезапно", вопросительные и восклицательные знаки, троеточия (паузы), нарушающие ритм, словно герои, охваченные ужасом, пытаются преодолеть эту неподвижность, замедление времени.

Наверху за потолком кто-то не то стонет, не то смеется... Прислушиваюсь. Немного погодя на лестнице раздаются шаги. Кто-то торопливо идет вниз, потом опять наверх. Через минуту шаги опягь раздаются внизу; кто-то останавливается около моей двери и прислушивается. (А.Чехов, Москва, 1977, с.301)

Что делать? Позвать семью? Нет, не нужно. (А.Чехов, Москва, 1977, с.301)

- Аx, боже мой... ax, боже мой! -- бормочет она, жмурясь от нашей свечи.-- Не могу, не могу... (А.Чехов, Москва, 1977, с.302) 1977, c.302)

- Да помоги же ей, помоги! -- умоляет жена. -- Сделай что-нибудь! ( А.Чехов Москва,

- Простите,-- говорит она.-- Мне вдруг почему-то стало невыносимо тяжело... Я не выдержала и поехала сюда... У вас в окне свет и... и я решила постучать... Извините... Ах, если б вы знали, как мне было тяжело! Что вы сейчас делаете?(А.Чехов, Москва, 1977, с.303)

\footnotetext{
Атмосфера необъяснимого ужаса нагнетается - "страшные", "жутко", "ктото...прислушивается", "собачий вой", "мертвая"...
}

Жутко. Закрываю окно и бегу к постели. Щупаю у себя пульс и, не найдя на руке, ищу его в висках, потом в подбородке и опять на руке, и все это у меня холодно, склизко от пота. Дыхание становится все чаще и чаще, тело дрожит, все внутренности в движении, на лице и на лысине такое ощущение, как будто на них садится паутина. (А.Чехов, Москва, 1977, c.301)

Я иду за своей женой, слушаю, что она говорит мне, и ничего не понилаю от волнения. По-ступеням лестницы прыгают светлые пятна от ее свечи, дрожат наши длинные 
тени, ноги мои путаются в полах халата, я задыхаюсь, и мне кажется, что за мной что-то гонится и хочет схватить меня за спину. "Сейчас умру здесь, на этой лестнице,-- думаю я.-Сейчас..."(А.Чехов, Москва, 1977, с.302)

Боже мой, как страшно! Выпил бы еще воды, но уж страшно открыть глаза и боюсь поднять голову. Ужас у меня безотчетный, животный, и я никак помогу понять, отчего мне страшно: оттого ли, что хочется жить, пли оттого, что меня ждет новая, еще неизведанная боль.(А.Чехов, Москва, 1977, с.301)

Никто ничего не может понять - логика и разум становятся бессильны: "никак не могу понять", "почему-то кажется", "ужас безотчетный", "почему-то стало невыносимо тяжело", "ничего не понимаю от волнения". Непонимание передается множеством вопросительных предложений:

-Почему кажется? (А.Чехов, Москва, 1977, с.300)

-- Киви-киви! -- раздается вдруг писк в ночной тишине, и я не знаю, где это: в моей груди или на улице? (А.Чехов , Москва, 1977, с.301)

...я никак помогу понять, отчего мне страшно: оттого ли, что хочется жить, или оттого, что меня ждет новая, еще неизведанная боль? (А.Чехов, Москва, 1977, с.301)

-Что с тобой? (А.Чехов, Москва, 1977, с.302)

-Что же я могу сделать? (А.Чехов, Москва, 1977, с.302)

И, хотя Николай Степанович по привычке прибегая к логике, как к спасению, пытается чтото объяснить, но ничего не выходит, объяснения не удовлетворяют его самого.

Как нарочно, в нашем дворе раздается вдруг собачий вой, сначала тихий и нерешительный, потом громкий, в два голоса. Я никогда не придавал значения таким приметам, как вой собак или крик сов, но теперь сердце мое мучительно сжимается и я спешу объяснить себе этот вой.

"Пустяки...-- думаю я. -- Влияние одного организма на другой. Мое сильное нервное напряжение передалось жене, Лизе, собаке, вот и все... Этой передачей объясняются предчувствия, предвидения..." (А.Чехов, Москва, 1977, с.302)

В отличие от предыдущих глав, здесь не физическое проявление болезни, а именно тишина, неподвижность и великолепие лунной ночи создают у героя иррациональное ощущение смерти на пороге.

Мне почему-то кажется, что я сейчас внезапно умру. Почему кажется? В теле нет ни одного такого ощущения, которое указывало бы на скорый конец, но душу мою гнетет такой ужас, как будто я вдруг увидел громадное зловещее зарево. (А.Чехов, Москва, 1977, c.300)

Но время не только замедляет ход и останавливается, оно начинает обратный отсчет, и герои словно попадают в прошлое - в детство и молодость, когда они еще способны были искренне чувствовать, искренне любить друг друга. Николай Степанович вдруг начинает 
видеть своих близких такими, какие они сохранились только в его памяти.

Увидев меня, она вскрикивает и бросается мне на шею.

-- Папа мой добрый... -- рыдает она, -- папа мой хороший... Крошечка мой, миленький... Я не знаю, что со мною... Тяжело!

Она обнимает меня, целует и лепечет ласкательные слова, какие я слышал от нее, когда она была еще ребенком. (А.Чехов, Москва, 1977, с.302)

Я стараюсь укрыть ее, жена дает ей пить, и оба мы беспорядочно толчемся около постели; своим плечом я толкаю ее в плечо, и в это время мне вспоминается, как мы когда-то вместе купали наших детей. (А.Чехов, Москва, 1977, с.302)

Брови ее поднимаются, глаза блестят от слез, и все лицо озаряется, как светом, знакомым, давно невиданным выражением доверчивости.(А.Чехов, Москва, 1977, с.303)

Возвращение в прошлое рождает на фоне совместно переживаемого ужаса настоящие живые чувства - любовь, жалость, искреннее желание понять и помочь. Этот момент в повести, максимальное сближение героев, дает надежду, что что-то можно изменить, душевная разобщенность ставших чужими людей может исчезнуть.

Однако, и эта надежда тает, все возвращается, они по-прежнему, не слышат и не понимают друг друга. Николай Степанович ничего не понимает, не знает и может только бормотать , он не в состоянии что-либо придумать, чтобы помочь Лизе, кроме, как выписать никому ненужный в данный момент рецепт, да и его не выписывает, а просто ждет, когда стоны за потолком умолкнут. Ему кажется, что и Катя, предлагая ему деньги, не слышит в его словах о том, что деньги теперь для него бесполезны, намек о близкой смерти и совершенно неправильно понимает его отказ.

Последняя 6-ая глава, следующая за "воробьиной ночью" начинается короткой фразой: "Я в Харькове".(А.Чехов, Москва, 1977, с.304) Прошел вне текста записок какой-то промежуток времени, и снова изменилось пространство - на этот раз оно абсолютно новое для героя, но для него все уже стало неважно. Основное настроение начала этой главы - равнодушие, что воспринимается как сильный контраст после пережитых эмоций и доходящего до предела напряжения "воробьиной ночи".

В Харьков ехать, так в Харьков. К тому же в последнее время я так оравнодушел ко всему, что мне положительно все равно, куда ни ехать, в Харьков, в Париж ли, или в Бердичев. (А.Чехов, Москва, 1977, с.304)

В душе героя - полнейшая пустота, даже к медленно уходящему времени он равнодушен, он слушает, как бьют часы, отбивая час за часом, отмечает начало боли в щеке, но ничто его уже не трогает, он только ждет проявлений болезни и смерти. Оставляет равнодушным его и неудачный брак дочери.

В коридоре часы бьют час, потом два, потом три... Последние месяц моей жизни, пока я жду смерти, кажутся мне гораздо длиннее всей моей жизни. И никогда раньше я не умел так мириться с медленностию времени, как теперь. Прежде, бывало, когда ждешь на вокзале поезда или сидишь на экзамене, четверть часа кажутся вечностью, теперь же я могу всю ночь сидеть неподвижно на кровати и совершенно равнодушно думать о том, что завтра будет такая, же длинная, бесцветная ночь, и послезавтра...

В коридоре бьет пять часов, шесть, семь... Становится темно.(А.Чехов, Москва, 1977, 
c.305)

Отмечая свое равнодушие, Николай Степанович выносит себе приговор.

Говорят, что философы и истинные мудрецы равнодушны. Неправда, равнодушие -- это паралич души, преждевременная смерть.

Я побежден. Если так, то нечего же продолжать еще думать, нечего разговаривать. Буду сидеть и молча ждать, что будет.(А.Чехов, Москва, 1977, с.305)

Чувств уже нет, и он снова возвращается к своим мыслям, к все тем же рассуждениям, "брюзжанию", возвращаются те же темы, что в начале повести - противоречие знаменитого имени и человека, философия стоиков, мировоззрение варвара и раба, недовольство плохими условиями и т.д. И на этом фоне, из этих рассуждений и рождается вывод о том, что причина происшедшего - отсутствие общей идеи в его жизни.

Последная сцена - неожиданный приезд Кати.

Мгновенно меняется ритм и лексика. Вместо вяло, медленно текущих рассуждений читаем

"порывисто встает","задыхаясь и дрожа всем телом", "падает на стул и начинает рыдать", "ломает руки", "топочет ногами", "падают", "рыдает", "хватая".

Ритм прерывистый, в тексте снова, как и в "воробьиную ночь" появляется множество вопросительных и восклицательных знаков, троеточий - пауз, тем более напоминающими драматургические чеховские приемы, что эта сцена - диалог, больше похожий на монолог.

Усиливаются паузы словом молчание, которое на двух страницах повторяется трижды.

Сама ситуация по сравнению с воробьиной ночью, казалось бы, повторяется - герой один, неожиданно появляется Катя, диалог, прощание, даже слово прощай.

От равнодушия героя не остается и следа. Он "растерялся, сконфужен, тронут рыданиями и едва стоит на ногах", "и тотчас же прибавляет упавшим голосом:

- Меня скоро не станет, Катя..."(А.Чехов, Москва, 1977, с.309)

Но "выражение лица уже сухо, сурово", основным словом - деталью становится "холод"."Отвечает она холодно", "холодно улыбнувшись" и "рука

у нее холодная, словно чужая". Холод, исходящий от Кати, деталь, напоминающая о смерти.

Финал повести поражает своей эмоциональной насыщенностью.

Мне хочется спросить: "Значит, на похоронах у меня не будешь?" Но она не глядит на меня, рука у нее холодная, словно чужая. Я молча провожаю ее до дверей... Вот она вышла от меня, идет по длинному коридору, не оглядываясь. Она знает, что я гляжу ей вслед, и, вероятно, на повороте оглянется.

Нет, не оглянулась. Черное платье в последний раз мелькнуло, затихли шаги... Прощай, мое сокровище! (А.Чехов, Москва, 1977, с.310)

Стиль возвышенный, трагический и сдержанный. Все то же настоящее время глаголов, но, как и в "воробьиную ночь", они растягивают каждое мгновение, на этот раз, потому что Николаю Степановичу хочется задержать время. И впервые вдруг появляются глаголы прошедшего времени совершенного вида , многократно усиливая трагизм, “растерялся" "не оглянулась", "мелькнуло", "затихли", подчеркивая, что эти, самые драгоценные минуты 
мгновенно оказываются в прошлом.

Неожиданно для лексики героя и слово сокровище. Возможно, эпитет относится не только к Кате, но и к уходящей стремительно жизни, которая внезапно, благодаря нахлынувшим чувствам, приобретает прежнюю ценность.

Очень значимы здесь слова молчание, молча. В самые трагические или эмоциональные минуты "молчание" становится единственно возможной формой выражения. Самое глубокое и сложное не поддается логическому анализу, рассуждениям и выводам, природа этого трагизма необъяснима. И поэтическая сила этого финала намного более сокрушительна и впечатляюща, чем раздумья об общей идее.

Усиливают это впечатление и некоторые отсылки к предыдущим страницам текста шуршание Катиного платья, когда мы впервые встречаем еe на страницах повести повторяется в последней сцене, Николай Степанович прежде сравнивал Катину апатию с настроением пассажира, ожидающего поезда, теперь то же сравнение применяет к себе.

Стилистически музыкальное звучание финала очень близко к наиболее ранними воспоминаниями, что снова дает нам возможность предположить не крах героя (как трактуется финал подавляющим числом критиков), а , напротив , возвращение его души к настоящим, живым чувствам.

2.

Как уже можно было заметить, прежде всего с темой времени связано само настроение "записок"- человек смертельно болен, жить ему осталось считанные месяцы, он вспоминает прошлое, анализирует настоящее, мысли о приближающейся смерти постоянно преследуют его, и, оказывается, ему нечем заполнить последние уходящие мгновения. То, что раньше наполняло смыслом, вдохновением и энтузиазмом его жизнь - наука, преподавание становятся для него почти невозможным в силу его физического состояния, а находить энергию и смысл в чем-либо другом он не привык. Жизнь течет как текла, ничего не меняется, и драгоценные минуты уходят впустую. Растерянность, раздражение и страх становятся его основными чувствами. Он ищет виновных среди близких, знакомых, учеников, сравнивая прошлое и теперешнее времена, потом винит себя. Возникает ощущение, что спасение от бессмысленности жизни было, и если бы он когда-то, вовремя, это понял, то жизнь сложилась бы удачнее, а последние мгновения не были бы отравлены.

Текст повести в книжном варианте (собр.соч.) составляет всего 60 страниц. но

в нем присутствуют практически все существующие категории времени - секунда, минута, четверть часа, полчаса, час, день, неделя, месяц, год, век вечность, вся жизнь, бесконечность, прошлое, будущее, например, слово минута повторяется 20 раз, час -28 , год -38 и т.д..

Неоднократно встречается само слово время и относящаяся к нему лексика.Все записки оказываются пронизанными временем, осознание героем своего "жития" соотносится с точными указаниями времени суток, года, с тем, сколько минут, часов, лет прошло с того или иного события.Указывается не только его собственный, но и возраст других персонажей. Для читателя становится возможным проследить и восстановить некоторые точные даты и длительность событий. Особенно это заметно на примере Катиной жизни, легко восстанавливаются время событий как ее, так и жизни самого Николая Степановича и его семьи.

Это не только характеризует Николая Степановича как человека, привыкшего говорить точным, научным языком и приводить точные цифры, но и создает впечатление, что в подсознании героя идет постоянный отсчет ушедшего и уходящего времени, что 
подчеркивается стилистикой и ритмом, то замедляющим, то убыстряющим ход.

Николай Степанович, обращаясь к своему прошлому, сравнивает прошедшие времена с нынешними, прошлых студентов с настоящими, самого себя до болезни и свое нынешнее состояние, своих близких в настоящем с теми, какие они были раньше, помимо прежде, теперь постоянно встречаются слова когда-то, сейчас, в прошлом, помню, до сих пор.

Поводом для размышления становится не только прошлое и настоящее, то что происходит ежедневно и в данный момент, но и будущее, находящееся уже за пределами его жизни.

Исходя из приведенных выше примеров видно, что есть "субъективное" время героя, каково отношение Николая Срепановича к нему, как много места занимает время в его мыслях , его ощущениях, восприятии жизни в целом.

"Субъективное" время для Николая Степановича, во-первых, - это протяженность написания записок. Мы можем восстановить длительность этого процесса. В начале записок упоминаются шубы и перчатки, следовательно, время года - зима или ранняя весна, герой говорит о том, что жить ему осталось не более полугода, затем "наступает лето", и герой предполагает, что умрет через три месяца. Из этого можно сделать вывод, что записки писались около трех- четырех месяцев.

Во-вторых - его прошлая жизнь, его воспоминания, первые из которых относятся к детству и юности, затем следуют воспоминания, относящиеся практически ко всем периодам его жизни до настоящего момента. По протяженности - это около 50-ти лет.

И, наконец, будущее, которого в жизни героя, по его мнению, у него нет, будущее связано со смертью . Герой думает как о ближайших моментах после его смерти, о том, будет ли Катя на его похоронах, кто будет преподавать вместо него в университете, так и о значительно более далеких.

Хотел бы проснуться лет через сто и хоть одним глазом взглянуть, что будет с наукой. ( А.Чехов Москва, 1977, с.307)

Обратимся к пространству, в котором существует Николай Степанович. Это Москва (университет, его квартира, Катина квартира), дача (его и Катина) и Харьков (номер в гостинице). Ежедневно и ежегодно (за исключением Харькова) жизнь его проходит по одним и тем же дорогам, он присутствует в одних и тех же стенах, общается с одними и теми же людьми.

Одеваюсь и иду по дороге, которая знакома мне уже 30 лет и имеет для меня свою историю. (А.Чехов, Москва, 1977, с.257)

Университет, пространство, в котором герой раньше чувствовал себя по-настоящему "дома", именно с этим пространством связано лучшее, что было, по мнению героя, в его жизни - цель, наука, вдохновение, упоение работой, признание.. В этом пространстве существуют швейцар Николай и Петр Игнатьевич, персонажи, которым отведено определенное место в записках. Особенно интересен для нас тезка (возможно, неслучайно), профессора Николай - хранитель университетских преданий, носитель того, что Ю. Лотман назвал "мифологическим пространством". В его мире существуют университетские легенды, великие герои-профессора и совершаются подвиги во имя науки.

Однако, все это в прошлом, в настоящем же - беспомощность, страх и стыд за свое состояние и неспособность вовремя уйти. То, что раньше давало сильнейший эмоциональный заряд, уверенность в своем таланте ученого и лектора превратилось в мучение, доходящее до панического ужаса.

В момент, когда пишутся записки университет, оставшись в памяти, возможно, любимым, 
наиболее психологически комфортным для него пространством перестает быть таковым в настоящем. Жизнь, проходящая в стенах университета, становится такой же рутиной, привычкой, от которой он не в силах отказаться, как и жизнь дома.

Казалось бы, домашний покой - основа для психологического спокойствия.

Обитатели этого пространства - семья - дочь Лиза и жена Варя, подруги и жених дочери Адольф Гнеккер, посетители - коллеги и студенты. - таков круг ежедневно, повторяющихся людей, семейных обедов, работы, мелких дел и событий. С точки зрения профессора, круг, ставший невыносимым по-сравнению со счастливой прошлой домашней жизнью. Дома стало так же некомфортно психологически, как и в университете, настолько некомфортно, что выход один - бегство.

Спасением, бегством для героя представляется перемещение из одного пространства в другое, на этот раз, из своей квартиры - в Катину.

Персонажи, обитающие здесь - хозяйка квартиры - повзрослевшая Катя (Катя- ребенок, как член семьи, появляется в воспоминании, в пространстве дома) и Михаил Федорович. Но несмотря на "тепло, уютную обстановку и присутствие симпатичного человека" (А.Чехов, Москва, 1977, с.281), дружеское общение за бокалом вина, желание Кати создать ему атмосферу душевного покоя, несмотря на все это, результат все тот же - раздражение, снова бегство, снова стыд.Но бегство, теперь, не дающее надежды на спасение, идти больше некуда - только домой, туда, откуда недавно бежал.

А потом -- бессонница.,.(А.Чехов, Москва, 1977, с.303)

Круг тесноты, скуки , "отравленного воздуха" замыкается.

Переезд на дачу, и "жизнь меняется"(А.Чехов, Москва, 1977, с.291) - оказывается всего лишь новой надеждой на то, что с изменением пространства изменится и жизнь. Но все продолжается по-прежнему (за исключением эпизода "воробьиной ночи") - те же лица (Лиза, жена, Гнеккер, Петр Игнатьевич, Николай), те же разговоры, та же бессоница. Только состояние напряжения растет. Николай, который всегда был симпатичен профессору "скоро наскучает" ему. Снисходительность к Петру Игнатьевичу и раздражение против Гнеккера превращаются в ненависть и презрение. И "обед у нас проходит скучнее, чем зимой"(А.Чехов, Москва, 1977, с.292) Учащаются вспышки и последующее чувство стыда. В ответ на реплику жены о том, что неприлично часто бывать в Катином обществе, у героя начинается истерика, заканчивающаяся обмороком.

И у Кати на даче все так же, как и в московской квартире - она сама, Михаил Федорович, те же разговоры, то же шампанское, те же карты. Хотя, кое-что, в состоянии Николая Степановича меняется - он уже не негодует. Усилившиеся страх, одиночество и стыд рождают желание сблизиться с людьми, хотя бы на почве злословия, тяга к сближению становится сильнее, чем негодование.

И, наконец, последнее место, где профессор пишет свои записки, место, в котором они для нас, читатателей, заканчиваются - город Харьков, неуютная гостиница. Полное одиночество и опустошение. Это уже не бегство, надежды уже нет, поездка эта вынужденная, и, как оказывается, бесполезная. Здесь Николай Степанович узнает о единственном значительном событии за то время, пока он пишет свои записки, событии, по-чеховски, остающимся "за кадром", катастрофичном , казалось бы, для отца - Лиза тайно вышла замуж за Гнеккера, который оказался мошенником. Но Николай Степанович равнодушен настолько, что пугается именно своего равнодушия.

В сущности, в Харькове герой осознает свое полное одиночество и понимает, что смена пространства всего лишь смена декораций, где бы он ни был, куда бы ни бежал, окружают ли его люди или нет, он везде остается один на один с самим собой, своей болезнью, своими мыслями, разочарованием и страхом. 
Мы проследили, как герой "записок" ощущает себя во времени и пространстве. Николай Степанович живет в бытовом времени, которое имеет начало и конец, и конец уже близок, в этом повторяющимся круговороте ежедневных событий настоящее не удовлетворяет его. Личное бытовое времени у него уже на исходе, и он обращается мыслями с одной стороны - к будущему, к вечности, а с другой - к прошлому, идеализированному, в котором неудовлетворенности не было, жизнь еще имела перспективы и не было необходимости задумываться о ценности каждого мгновения. Причины этой неудовлетворенности он ищет в окружающих его людях (пространство дома, университета), изменившемся времени ("нынешние" студенты, "нынешние" близкие, не похожие на "прошлых") наконец, в самом себе, своих мыслях и своем отношении к жизни. Рождается одиночество и отстраненность от людей, которую он пытается преодолеть. Один из способов такого преодоления для него бегство, но где бы он не находился, его личное пространство - его одиночество остается неизменным, и попытки преодолеть его- безрезультатными.

Мы уже отмечали, что по сравнению со временем и пространством, в которых существует автор записок, круг времени-пространства его знаменитого имени значительно более широк.

Что же можно сказать о хронотопе всей повести в целом, как понять замысел автора?

3.

В "Скучной истории" среди используемых художественных средств, мы встречаем упоминания знаменитых имен, цитаты, реминисценции и аллюзии, т.е. явные или скрытые отсылки к другим источникам, обогащающим смысловой подтекст произведения.

Есть несколько упоминаний Шекспира и его персонажей, и критикой это уже было отмечено, так же, как связь "Скучной истории" со "Смертью Ивана Ильича" Л. Толстого, и с "Фаустом" Гете.

Остановимся на нашей гипотезе, заключающейся в том, что вышеперечисленные художественные средства в повести играют не только основную традиционную роль, но и вместе со "случайными" деталями и географическими названиями расширяют ее время и пространство.

Если мы расположим в хронологическом порядке упоминания и отсылки к "чужим" текстам и знаменитым именам мы увидим, что охваченной оказывается вся история человечества от Ветхого завета и античности, через средние века и Возрождение до Нового времени, весь 19 век и даже будущее.

Приведем несколько примеров:

Ветхий Завет (13 в. до н.э. -1 в.н.э.)

Часто я любуюсь, как какие-то мальчик и девочка, оба беловолосые и оборванные, карабкаются на палисадник и смеются над моей лысиной. В их блестящих глазенках я читаю: "гряди, плешивый!" (А.Чехов, Москва, 1977, с.294)

Античность (6 в. до н.э. -4-5 в. н.э)

Геркулес после самого пикантного из своих подвигов не чувствовал такого сладостного изнеможения, какое переживал я всякий раз после лекций. (А.Чехов, Москва, 1977, с.263)

Одним словом, до Гекубы ему нет никакого дела (А.Чехов, Москва, 1977, с.260) 
-Эпиктет (50 -138 г.г.)

-Марк Аврелий (161 - 180 г.г.)

...совершенно равнодушны к таким классикам, как, например, Шекспир, Марк Аврелий, Епиктет или Паскаль. (А.Чехов, Москва, 1977, с.288)

-средние века :

Современная женщина так же слезлива и груба сердцем. как и в средние века". (А.Чехов, Москва, 1977, с.275)

-несколько упоминаний Шекспира (1564-1616) или его персонажей

страстно полюбил за хороший, ясный ум, за чистую душу, красоту и, как Отелло Дездемону, за "состраданье" к моей науке? (А.Чехов, Москва, 1977, с.255)

-Новое время:

-Паскаль (1623 - 1662)

-Бах $(1685-1750)$

Барышни и Гнеккер говорят о фугах, контрапунктах, о певцах и пианистах, о Бахе и Брамсе...(А.Чехов, Москва, 1977, с.278)

-Именами или цитатами представлен весь 19 век, начиная с цитаты Крылова (из басни 1808 года)

Так случилось однажды, я долго глядел с презрением на Гнеккера и ни с того ни с сего выпалил:

Орлам случается и ниже кур спускаться,

Но курам никогда до облак не подняться... (А.Чехов, Москва, 1977, с.296)

-Аракчеев (1769-1834)

... мое миросозерцание может быть выражено словами, которые знаменитый Аракчеев сказал в одном из своих интимных писем: "Все хорошее в свете не может быть без дурного, и всегда более худого, чем хорошего". (А.Чехов, Москва, 1977, с.291)

- Чацкий ("Горе от ума") (1823-1827)

Когда актер, с головы до ног опутанный театральными традициями и предрассудками, старается читать простой, обыкновенный монолог "Быть или не быть" не просто, а почему-то непременно с шипением и с судорогами во всем теле, или когда он 
старается убедить меня во что бы то ни стало, что Чацкий, разговаривающий много с дураками и любящий дуру, очень умный человек и что "Горе от ума" не скучная пьеса, то на меня от сцены веет тою же самой рутиной, которая скучна мне была еще 40 лет назад. (А.Чехов, Москва, 1977, с.270)

-Тургенев, Дневник лишнего человека (1849)

Голова и руки у меня трясутся от слабости; шея, как у одной тургеневской героини, похожа на ручку контрабаса. (А.Чехов, Москва, 1977, с.252)

Некрасов (1821-1877),

Кавелин (1818-1885)

Пирогов (1810-1881)

Скобелев (1843-1882)

Будущее:

"Не знаю, что будет с театром через 50 - 100 лет..." (А.Чехов, Москва, 1977, с.270)

Хотел бы проснуться лет через сто и хоть одним глазом взглянуть, что будет с наукой. (А.Чехов, Москва, 1977, с.307)

Мы видим, необычайное расширение временных границ - от 13 в. до н.э до конца 20 в. В связи с этим и слово “история” преобретает в названии символический смысл .

Переходя к вопросу пространства в повести вспомним чеховские "случайные" детали

Во всех многочисленных способах использования вещи при изображении человека в дочеховской литературе есть общая черта. Предметный мир, которым окружен персонаж, - его жилье, мебель, одежда, еда, способы обращения персонажа с этими вещами, его поведение внутри этого мира, его внешний облик, жесты и движения, - все это служит безотказным и целенаправленным средством характеристики человека. Все без исключения подробности имеют характерологическую и социальную значимость. (А.Чудаков ,1971,с.139)

И постоянно мы встречаем у Чехова такие - как правило, очень мелкие - детали обстановки, черты внешности, цель и смысл которых невозможно истолковать, исходя из содержания и традиционно понимаемых задач того описания, в которое они включены.

( А.Чудаков ,1971 с.144)

Цель и смысл у деталей такого рода, разумеется, есть. В настоящем искусстве лишнего не бывает. Когда мы говорим об «ненужности» деталей - это следует понимать только в том смысле, что они «не нужны» с точки зрения других, нечеховских, художественных принципов.

Назначение, смысл, таких подробностей явно другой, чем в предшествующей литературной традиции. Эти детали - знаки какого-то иного, нового способа изображения, и в нем они важны и обязательны. (А.Чудаков ,1971, с.146)

В тексте "Скучной истории" очень много таких, казалось бы, случайных деталей. В том числе, встречается множество:

географических названий, ничем по сюжету не оправданных, "случайных". 
Россия, Европа, Варшава, Харьков, Ялта, Уфа, Крым, Кавказ, Волга, Ревель, Париж, Бердичев.

национальностей:

Все эти новости похожи одна на другую и сводятся к такому типу: один француз сделал открытие, другой -- немец -- уличил его, доказав, что это открытие было сделано еще в 1870 году каким-то американцем, а третий -- тоже немец -- перехитрил обоих, доказав им, что оба они опростоволосились, приняв под микроскопом шарики воздуха за темный пигмент. (А.Чехов, Москва, 1977, с.295)

Кажется, запой у него под самым ухом Патти, напади на Россию полчища китайцев, случись землетрясение, он не пошевельнется ни одним членом и преспокойно будет смотреть прищуренным глазом в свой микроскоп. (А.Чехов, Москва, 1977, с.260)

..но я все-таки не понимаю его присутствия; оно возбуждает во мне такое же недоумение, как если бы со мною за стол посадили зулуса.(А.Чехов, Москва, 1977, с.277)

несколько деталей такого же свойства:

По обыкновению, она лежит на турецком диване или на кушетке и читает чтонибудь.(А.Чехов, Москва, 1977, с.280)

Но вот миновали лестницу, темный коридор с итальянским окном и входим в комнату Лизы. (А.Чехов, Москва, 1977, с.302)

А если вспомнить о цитатах и реминисценциях, то получим еще Грецию (Гекуба), Рим (Марк Аврелий), Англию (Шекспир), Италию(Патти)

Таким образом, если подытожить, прямо или косвенно, мы получаем намеки- ассоциации или упоминания различных городов и стран - России (Варшава, Харьков, Ялта, Уфа, Крым, Кавказ, Волга, Бердичев), Европы (Германия, Англия, Франция, Греция, Италия), Ближнего востока ,Турции, Китая, Америки, даже Африки (зулус),что психологически, подсознательно вырывают читателя из душного тесного мира героя в широкий бесконечный мир.

Принято говорить, что человеку нужно только три аршина земли. Но ведь три аршина нужны трупу, а не человеку. Человеку нужно не три аршина земли, не усадьба, а весь земной шар, вся природа, где на просторе он мог бы проявить все свойства и особенности своего свободного духа. (А.Чехов, Москва, 1977, с.58)

Мы видим, что пространство, ограниченное в записках Москвой, дачей под Москвой и Харьковым, в повести расширяется и охватывает почти весь мир, так же, как время, ограниченное 3-4 месяцами записей и одной человеческой жизнью (по воспоминаниям) в повести охватывает всю историю человечества.

Так "индивидуализированный случай" принимает глобальный масштаб. Подобные "скучные истории" происходили и будут происходить всегда, независимо от эпохи в любой точке Земли.

Таким образом, можно заключить, что хронотоп повести не только расширяет 
многомерность повествования, но и создает, несмотря на лаконичность формы, философскую картину одной частной жизни на фоне общей истории человечества.

Библиография

А.Чехов Полное собрание сочинений и писем в 30 томах, Москва, 1977-1978

А.Чехов Полное собрание сочинений http://ruslit.traumlibrary.net/book/chekhov-pss30-21/chekhov-pss30-21.html (последний просмотр 09.03.2013)

.Ал. Чехов $\mathrm{B} \quad$ гостях дедушки ..http://az.lib.ru/c/chehow_aleksandr_pawlowich/text_0070.shtml(последний просмотр 09.03.2013)

A. Степанов Проблемы коммуникации у Чехова $\underline{\text { http://my- }}$ chekhov.ru/kritika/problem/content.shtml

.А.Чудаков Поэтика Чехова, Наука, Москва, 1971

Ю. Лотман Структура художественного текста http://www.e-reading.club/book.php?book=35262 http://philologos.narod.ru/lotman/gogolspace.htm

М. Бахтин М.М. Формы времени и хронотопа в романе. Вопросы литературы и эстетики. М.: Худож. лит., 1975. - С.234-407.

http://philologos.narod.ru/bakhtin/hronotop/hronmain.html 